\title{
Eradikasi Polio
}

Hindra Irawan Satari

Departemen Ilmu Kesehatan Anak Fakultas Kedokteran Universitas Indonesia/RS Dr. Cipto Mangunkusumo, Jakarta

\begin{abstract}
Abstrak
Poliomielitis atau yang lebih dikenal dengan polio merupakan penyakit menular yang dapat menyebabkan kelumpuhan dan atrofi otot yang ireversibel, bahkan kematian pada anak. Sejak dilaporkan kejadian luar biasa (KLB) terjadi di Eropa pada abad ke-19, angka kejadian polio terus meningkat hingga menjadi pandemi pada awal abad ke-20. Saat ini, gerakan inisiatif global yang dibentuk oleh WHO telah berhasil menurunkan angka insidensi polio sampai $80 \%$, berkat pemberian vaksin yang didukung oleh program pemerintah dan sistem pengawasan yang baik. Namun, muncul masalah terkait pemberian vaksin, oral poliovirus vaccine (OPV), yaitu circulating vaccine derived polio viruses (cVDPVs) dan vaccine associated paralytic poliomyelitis (VAPP). Untuk itu, American Academy of Pediatrics merekomendasikan pemberian inactivated poliovirus vaccine (IPV) sebagai pengganti OPV. Rekomendasi tersebut tidak efektif apabila diterapkan di negara berkembang yang masih banyak terdapat infeksi polio liar, seperti Indonesia, karena perlindungan IPV tidak cukup kuat, tidak dapat menimbulkan herd immunity, dan harganya jauh lebih mahal. Pemberian OPV masih menjadi pilihan, dengan rekomendasi terbaru dari WHO yang mempertimbangkan pemberian bivalent (bOPV) karena trivalent (tOPV) dapat meningkatkan angka kejadian cVDPV akibat virus polio tipe-2 (VP2). Upaya eradikasi polio ditunjang Global Polio Eradication Initiative (GPEI) melalui Eradication and Endgame Strategic Plan dengan target bebas polio pada tahun 2018. Sari Pediatri 2016;18(3):245-50
\end{abstract}

Kata kunci: eradikasi polio, cVDPV, VAPP, OPV, IPV

\section{Polio Eradication Program}

Hindra Irawan Satari

\begin{abstract}
Poliomyelitis, or better known as polio is a contagious disease that can cause irreversible paralysis and muscle atrophy, or even death in children. Since the reported outbreak in Europe in the $19^{\text {th }}$ century, the incidence of polio continue to rise to become a pandemic in the early $20^{\text {th }}$ century. Currently, global initiatives set up by the WHO has been successful in reducing the incidence of polio by $80 \%$, due to vaccines that are supported by government programs and good surveillance system. However, new problems arise related to the vaccine, especially oral poliovirus vaccine (OPV), which is circulating vaccine derived polio viruses (cVDPVs) and vaccineassociated paralytic poliomyelitis (VAPP). Therefore, the American Academy of Pediatrics recommends the use of inactivated poliovirus vaccine (IPV) instead of OPV. The recommendation is not effective when applied in developing countries, such as Indonesia, where there are still many wild polio infection, for the protection of IPV is not strong enough, would not result in herd immunity, and much more expensive. Thus, administration of OPV is still an option, with the recent recommendation of WHO was considering giving bivalent form of OPV (bOPV) since the trivalent form of OPV (tOPV) enhances the incidence of cVDPV which is also supported by a minimum number of VP2 infection. So, the importance of polio eradication itself creates a new movement of the Global Polio Eradication Initiative (GPEI) through Eradication and Endgame Strategic Plan with a target polio-free in 2018. Sari Pediatri 2016;18(3):245-50
\end{abstract}

Keywords: polio eradication, cVDPV, VAPP, OPV, IPV

Alamat korespondensi: DR. Dr. Hindra Irawan Satari, SpA(K). Departemen Ilmu Kesehatan Anak Fakultas Kedokteran Universitas Indonesia/RS Dr. Cipto Mangunkusumo, Jakarta. Email:hsatari@yahoo.com 
$\mathrm{P}$ oliomielitis merupakan penyakit menular yang dapat menyebabkan paralisis ireversibel dan kematian pada anak. ${ }^{1}$ Predileksi virus polio pada sel kornu anterior medula spinalis, inti motorik batang otak dan area motorik korteks otak, menyebabkan kelumpuhan serta atrofi otot. ${ }^{2}$ Mengingat penyakit ini menyebabkan kelumpuhan, maka polio menjadi salah satu penyakit yang penting untuk dieradikasi secara global. Dunia sangat beruntung karena ditemukan vaksin yang efektif untuk mencegah polio. Dikenal dua jenis vaksin polio, yaitu oral polio vaccines $(O P V)$ dan inactivated polio vaccines (IPV). ${ }^{3}$ Namun terdapat masalah, yaitu circulating vaccine derived polio viruses (cVDPVs) dan kejadian vaccine associated paralytic poliomyelitis (VAPP), yang merupakan kasus polio paralitik yang disebabkan oleh virus vaksin. ${ }^{2}$ Maka pemakaian OPVdiubah dari tOPV menjadi bOPV. ${ }^{4,5}$

Di saat ini, dunia hampir tiba pada masa eradikasi penyakit. Para ilmuwan telah bergabung untuk mendukung program eradikasi polio, dengan target bebas polio di tahun 2018, melalui Eradication and Endgame Strategic Plan, suatu strategi gerakan Global Polio Eradication Initiative (GPEI). ${ }^{1}$

\section{Sejarah}

Kata poliomielitis berasal dari istilah medis untuk menggambarkan dampak virus polio pada medula spinalis. Polio berasal dari bahasa Yunani yang berarti abu-abu dan saraf tulang belakang (myelon). ${ }^{6}$ Polio diduga pertama kali dikenal kira-kira 6000 tahun yang lalu. Pada mumi dari zaman Mesir kuno ditemukan kelainan kaki, dan pada deskripsi Mesir kuno di tahun 1580-1350 sebelum Masehi yang digambarkan pendeta muda dengan sebelah kaki atrofi dan telapak kaki pada posisi equinus. ${ }^{2}$ Deskripsi klinis pertama mengenai poliomielitis dibuat oleh Michael Underwood, seorang dokter dari Inggris yang melaporkan penyakit yang terutama menyerang anak-anak dan menyebabkan kelumpuhan menetap pada ekstremitas bawah. ${ }^{6}$ Pada awal abad ke-19 dilaporkan kejadian luar biasa polio di Eropa dan pertama kali dilaporkan di Amerika Serikat pada tahun 1843. Namun, angka kejadian polio terus meningkat menjadi epidemi di awal abad ke-20. ${ }^{6}$

\section{Etiologi}

Virus penyebab polio pertama kali ditemukan di tahun 1909 oleh Karl Landsteiner dan Erwin Popper, dua orang dokter dari Austria. ${ }^{6}$ Virus polio (VP) adalah virus RNA ultra mikroskopik yang termasuk genus Enterovirus, dalam famili Picornaviridae. ${ }^{2}$ Virus single stranded $30 \%$ terdiri dari virion, protein mayor (VP1 sampai 4) dan satu protein minor (VPg). Virus terdiri dari 3 serotipe yaitu serotipe 1, 2, dan 3 masing-masing disebut juga serotipe Mahoney, Lansing, dan Leon. Perbedaan ketiga jenis strain terletak pada segmen nukleotida. Virus polio serotipe 1 adalah antigen yang paling dominan dalam membentuk antibodi netralisasi. Serotipe 1 adalah yang paling paralitogenik dan sering menimbulkan KLB, sedangkan serotipe 3 adalah yang paling tidak imunogenik. ${ }^{2,6}$

\section{Patogenesis}

Virus polio ditularkan lewat jalur fekal-oral. Virus dapat diisolasi dari sistem limfatik saluran cerna manusia, termasuk tonsil, Peyer's patch, dan kelenjar getah bening usus, juga dalam feses. Replikasi awal virus pada sel yang rentan infeksi di faring dan saluran cerna sebagian besar akan menimbulkan viremia minor dan singkat, serta asimtomatik. Apabila infeksi berlanjut, virus akan menyebar lebih luas pada jaringan retikuloendotelial lainnya. Dilaporkan 95\% infeksi primer ini asimtomatik, dan pada 4\%-8\% infeksi sekunder akan muncul sebagai gajala infeksi virus non spesifik. Apabila infeksi tersebut sudah menginvasi sistem saraf, dapat terjadi meningitis aseptik pada $1 \%-2 \%$ kasus, dan terjadi polio paralitik pada $0,1 \%-1 \%$ kasus. ${ }^{1,6}$

Berdasarkan manifestasi klinis spesifik, poliomielitis paralitik tanpa gejala sensoris dan gangguan fungsi kognitif. Secara klinis, polio diklasifikasikan sebagai berikut, ${ }^{6}$

1. Poliomielitis spinal, ditandai dengan acute flaccid paralysis (AFP) atau lumpuh layu akut, sekunder akibat destruksi selektif dari motor neuron pada medula spinalis dan sekuens denervasi dari struktur muskuloskeletal yang terlibat

2. Poliomielitis bulbar, terdapat paralisis otot pernafasan akibat serangan virus pada neuron di batang otak yang mengontrol pernafasan

3. Poliomielitis bulbo-spinalis akibat kerusakan batang otak dan medula spinalis. 
Tabel 1: Klasifikasi famili Picornaviridae

\begin{tabular}{llc}
\hline Genus & Type spesies & Serotipe \\
\hline Enterovirus & Poliovirus & 3 \\
& Human enterovirus & A 17 \\
& Human enterovirus B & 56 \\
& Human enterovirus C & 13 \\
& Human enterovirus D & 3 \\
& Simian enterovirus A & 1 \\
& Bovine enterovirus & 2 \\
& Porcine enterovirus B & 2 \\
\hline Rhinovirus & Human rhinovirus A & 74 \\
& Human rhinovirus B & 25 \\
\hline Cardiovirus & Encephalomyocarditis virus & 1 \\
& Theilovirus & 3 \\
\hline Aphtovirus & Foot-and-mouth disease virus & 7 \\
\hline Equine & rhinitis A virus & 1 \\
\hline Hepatovirus & Hepatitis A virus & 1 \\
& Avian encephalomyelitis-like virus & 1 \\
\hline Parechovirus & Human parechovirus & 3 \\
& Ljungan virus & 2 \\
\hline Erbovirus & Equine rhinitis B virus & 2 \\
\hline Kobuvirus & Aichi virus & 1 \\
\hline Teschovirus & Bovine kobuvirus & 11 \\
& Porcine teschovirus &
\end{tabular}

Dikutip dari ${ }^{6}$

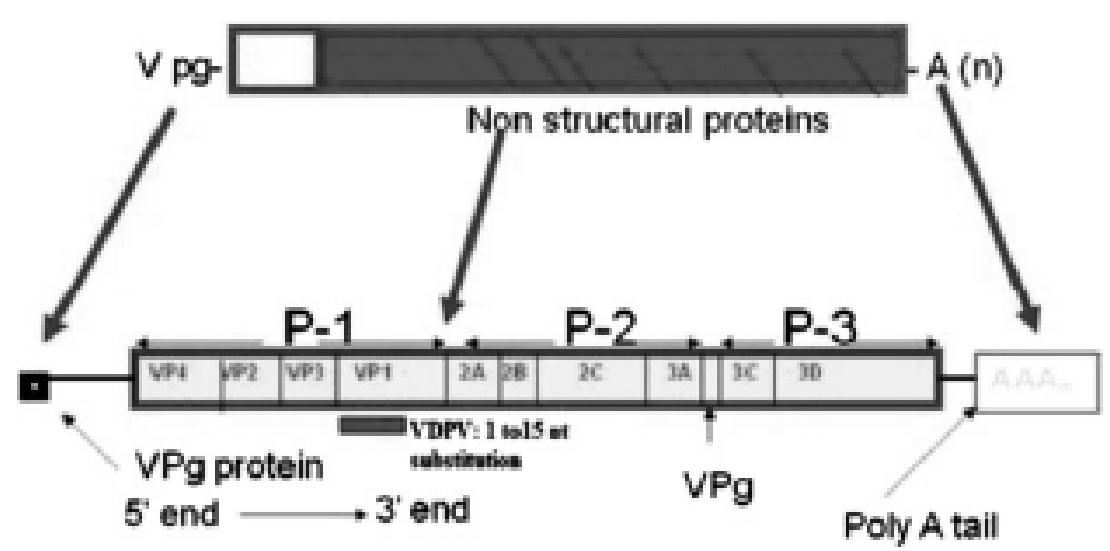

Gambar 1. Struktur virus polio ${ }^{\text {Dikutip dari } 7}$

Diantara kasus poliomielitis paralitik, diperkirakan angka fatality rate $2 \%-5 \%$ pada anak-anak dan $15 \%$ $30 \%$ pada dewasa, dengan peningkatan kematian pada paralisis bulbar. ${ }^{6}$

\section{Epidemiologi}

Pada tahun 1988, menteri kesehatan dari berbagai negara anggota World Health Organization (WHO) 
menyerukan gerakan eradikasi polio. Hasil dari gebrakan ini adalah menurunnya insidens polio lebih dari 99\% pada tiga regional WHO (Amerika, Pasifik Barat, dan Eropa) dan mendapat sertifikasi bebas polio. Program intensif untuk eradikasi polio di Asia Tenggara dengan menggunakan trivalent OPV (tOPV) menyebabkan penurunan angka kejadian polio. ${ }^{7}$

Tahun 2012 disebut sebagai titik balik bagi negaranegara endemis polio. Kasus baru infeksi virus polio liar berkurang dari perkiraan 350.000 kasus di 125 negara (pada tahun 1988) menjadi hanya 748 kasus di tahun 2000, dan kurang dari 250 kasus di lima negara pada tahun 2012., India dinyatakan telah berhasil menghentikan transmisi virus polio liar di tahun 2011. ${ }^{1}$ Saat ini, hanya tinggal dua negara yang masih endemis polio, yaitu Pakistan dan Afganistan. Nigeria yang sebelumnya juga termasuk negara endemis, sudah tidak melaporkan lagi kasus polio liar sejak 24 Juli 2014 dengan didukung oleh surveillance AFP yang baik. ${ }^{14}$

\section{Vaksin polio}

Sejak pengenalan vaksin poliovirus di tahun 1950 dan awal tahun 1960an, efektivitas vaksin untuk mencegah poliomielitis telah dibuktikan secara nyata. Kasus polio terakhir di Amerika Serikat yang disebabkan oleh virus polio liar dilaporkan pada tahun 1979. Tidak ada kasus baru yang dilaporkan di negara barat sejak Agustus 1991, dan hal ini membuat Amerika mendapat sertifikasi bebas polio dari komisi internasional di tahun $1994 .^{5}$ Fakta ini membuat pemikiran positif bahwa polio dapat dieradikasi di dunia.

Jenis vaksin polio

1. Oral poliovirus vaccine (OPV)

OPV sering disebut sebagai vaksin polio Sabin sesuai nama penemunya, bentuk trivalen (tOPV) untuk mencegah tiga jenis virus polio. Vaksin tOPV adalah vaksin hidup yang dilemahkan (liveattenuated virus vaccine), diberikan tiga dosis secara serial untuk memberikan kekebalan seumur hidup. Vaksin polio oral lebih efektif untuk pemberantasan poliomielitis, karena virus yang dilemahkan akan mengadakan replikasi di traktus gastrointestinalis bagian bawah. Hal ini dapat menutup replikasi virus sehingga virus lain tidak dapat menempel dan menyebabkan kelumpuhan. Kemampuan ini dapat menekan transmisi virus saat KLB. Namun, vaksin OPV adalah virus yang dilemahkan, yang dapat mengalami mutasi sebelum dapat bereplikasi dalam usus dan diekskresi keluar. Hal ini menimbulkan kerugian berupa munculnya circulating vaccine derived polio viruses (cVDPVs) dan vaccineassociated paralytic poliomyelitis (VAPP). ${ }^{2,3,5}$ Saat ini, mulai dipertimbangkan pemberian vaksin OPV bivalent (bOPV) yang berisi virus tipe 1 dan 3 sesuai rekomendasi WHO.?

\section{Inactivated poliovirus vaccine (IPV)}

Vaksin polio inaktif (IPV) sebenarnya lebih dulu ditemukan daripada OPV, disebut juga vaksin polio Salk, sesuai dengan nama penemunya Jonas Salk di tahun 1955. Vaksin IPV berisi virus inaktif, berisi 3 tipe virus polio liar. Vaksin yang disuntikkan akan memunculkan imunitas yang dimediasi IgG dan mencegah terjadinya viremia serta melindungi motor neuron. Vaksin IPV mampu mencegah kelumpuhan karena menghasilkan antibodi netralisasi yang tinggi. Pada tahun 1980an, komposisi awal IPV yang ditemukan Salk dikembangkan sehingga memiliki kandungan antigen yang lebih tinggi, dikenal sebagai enhancedpotency IPV (eIPV) dan digunakan sampai sekarang. Pemberian IPV pada berbagai studi dilaporkan dapat menyebabkan serokonversi terhadap ketiga tipe virus polio sebesar 94\% setelah pemberian dua dosis dan $99-100 \%$ setelah pemberian injeksi 3 dosis. Keuntungan lain IPV adalah dapat diberikan pada kasus dengan status immunocompromised. Namun bila dibandingkan dengan OPV, vaksin inaktif ini kurang kuat dalam memberikan perlindungan mukosa dan kurang efektif untuk menimbulkan herd immunity. Harga vaksin IPV ini juga relatif mahal. ${ }^{2,5,9,10}$ Di negara maju, pemberian IPV lebih direkomendasikan karena dapat mengurangi angka kejadian VAPP dan VDPV. ${ }^{4,5}$

\section{Eradikasi polio, masalah, dan target}

Gerakan inisiatif global untuk eradikasi polio yang dicanangkan oleh WHO sudah menurunkan insidens polio sampai lebih dari $80 \% .^{5}$ Selain pemberian vaksin, strategi untuk eradikasi polio ini perlu didukung dengan program pemerintah yang kuat dan sistem surveilans yang baik. ${ }^{1,9}$ Masalah utama yang muncul adalah bagaimana dapat melakukan eradikasi polio 
dengan vaksinasi, apabila vaksin yang dipergunakan dapat menyebabkan kelumpuhan.

Pemberian vaksin polio secara besar-besaran sejak tahun 1988 dengan tujuan eradikasi polio dapat tercapai di sebagian besar negara-negara dunia adalah karena efektifitas OPV. Namun harus diingat bahwa vaksin OPV adalah virus yang dilemahkan, yang dapat mengalami mutasi sebelum dapat bereplikasi dalam usus dan diekskresi. Mutasi ini terjadi pada sekuens nukleotida dari 5-prime-end dari regio nonkoding genom virus, melibatkan satu sampai beberapa nukleotida. Definisi cVDPV jika mutasi lebih dari 1\% koding genom RNA untuk viral capsid, dan isolate ini umumnya mengalami rekombinasi dengan enterovirus lain sehingga meningkatkan daya virulensi. Eksistensi cVDPV ditemukan di tahun 2000 selama penyelidikan 21 kasus paralitik poliomielitis di Hispaniola. Sebetulnya mutasi virus vaksin dapat terjadi namun tidak menjadi masalah (menyebabkan kasus) apabila tidak terdapat kantong-kantong anak yang tidak terimunisasi. Di negara yang masih memiliki angka polio tinggi, VDPV dapat menyebabkan KLB polio yang sulit diatasi. ${ }^{2,5,9-11}$ Sekurangnya ada enam KLB cVDPV yang muncul di dunia sejak tahun 2000, yaitu di Hispaniola (Haiti dan Republik Dominica, tahun 2000), Filipina (2001), Madagaskar (2003 dan 2005), China (2004) dan Indonesia (2005). ${ }^{12}$

Masalah lainnya adalah VAPP, yaitu kasus polio paralitik yang disebabkan oleh virus vaksin, dibagi menjadi VAPP resipien dan VAPP kontak. Kejadian VAPP resipien dijumpai pada kasus polio paralitik yang terjadi dalam waktu antara 7-30 hari setelah pemberian vaksin. Sementara VAPP kontak adalah kasus polio yang terjadi antara 7-60 hari setelah penderita kontak dengan penerima vaksin OPV, atau tinggal di daerah yang mengadakan imunisasi masal OPV dalam waktu 7-60 hari sebelum sakit. Di Amerika, masalah VAPP ini lebih menjadi perhatian. Sejak mendapat sertifikasi bebas polio (1979) hampir semua kasus paralitik poliomielitis adalah berhubungan VAPP. Antara tahun 1980 dan 1994, dilaporkan 125 kasus VAPP, dan saat itu masih dipakai vaksin OPV untuk imunisasi. Sejak itu dikembangkan pemberian IPV berdasarkan rekomendasi American Academy of Pediatrics mengenai pemberian IPV sebagai pengganti OPV., ${ }^{2,4,5}$

Di negara berkembang, tidak semudah itu menerapkan pemberian IPV. Pertama, harganya jauh lebih mahal dari OPV. Selain itu, di negara yang masih banyak infeksi virus polio liar, dikatakan perlindungan
IPV tidak cukup kuat dan tidak dapat menimbulkan herd immunity. Berdasarkan data infeksi virus polio yang digolongkan sesuai tipenya, didapatkan bahwa insidens infeksi virus polio tipe-2 (VP2) paling sedikit dibanding VP1 dan VP3 (Tabel 2). ${ }^{13}$ Bahkan, kasus VP2 tidak pernah lagi dilaporkan sejak tahun 1999. Oleh karena itu, pada tanggal 20 September 2015, WHO resmi menyatakan bahwa virus polio liar tipe 2 sudah musnah. ${ }^{15}$ Di lain pihak, angka kejadian cVDPV akibat VP2 cukup tinggi, terutama di Nigeria, Pakistan, dan Afghanistan. Bahkan lebih dari 90\% KLB poliomielitis disebabkan cDVPV2. Maka dibuat rekomendasi baru untuk mengalihkan tOPV (trivalen) ke OPV bivalen (bOPV) yang hanya mengandung virus polio tipe 1 dan 3.,7 Tentunya, kebijaksanaan ini mengandung risiko beredarnya virus polio tipe 2 , terutama cVDPV, sehingga jadwal imunisasi polio minimal satu kali diberikan dan berisi 3 serotipe polio. ${ }^{9}$

Berdasarkan hal tersebut, dibuat strategi menuju eradikasi polio di dunia yaitu,

1. Pemberian tOPV beralih ke bOPV yang dilakukan serentak di seluruh dunia pada bulan April 2016.

2. Mengenalkan setidaknya 1 dosis IPV pada imunisasi rutin sebagai "priming". Maka jika terjadi KLB polio karena cVDPV type2, akan langsung terjadi booster (penguat). Untuk Indonesia, IPV disarankan diberikan bersamaan dengan pemberian OPV yang terakhir.

3. Memberhentikan penggunaan OPV dan melanjutkan dengan IPV saat infeksi virus polio liar sudah tidak ada di dunia.

4. Melakukan penelitian untuk memproduksi IPV dengan harga murah dan terjangkau.

\section{Kesimpulan dan saran}

Kelebihan OPV dibanding IPV adalah lebih murah, cara pemberian lebih mudah, dan daya imunogenisitas lebih tinggi, serta efektif menekan transmisi virus saat wabah.

Tabel 2. Virus polio liar di Asia Tenggara, 1997-1999

\begin{tabular}{lccc}
\hline Poliovirus Type & 1997 & 1998 & 1999 \\
\hline Type 1 & 634 & 1741 & 429 \\
Type 2 & 3 & 83 & 11 \\
Type 3 & 78 & 192 & 732 \\
\hline Total & 715 & 2016 & 1172 \\
\hline
\end{tabular}

Dikutip dari ${ }^{13}$ 
Kerugian tOPV yang saat ini dipakai adalah VDPV dan VAPP. Sedangkan IPV sebaliknya, menghasilkan antibodi netralisasi yang tinggi, mengurangi risiko VAPP, namun karena harganya cukup mahal maka belum dapat digunakan untuk program imunisasi masal di negara-negara berkembang. Vaksinasi IPV juga tidak mempunyai efek untuk menekan transmisi di daerah dengan endemis polio. ${ }^{2,9}$ Diperlukan usaha dan komitmen bersama dari semua negara untuk melaksanakan strategi eradikasi polio di dunia.

\section{Ucapan terimakasih}

Terimakasih kepada Laila Fitri Ibbibah, Sidik Utoro yang telah membantu penyelesaian naskah ini.

\section{Daftar pustaka}

1. Bhutta ZA, Orenstein WA. Scientific declaration on polio eradication (on behalf of Scientific Experts Against Polio). Vaccine 2013;31:2850-1.

2. Soedarmo SSP, Gama H, Hadinegoro SRS, Satari HI. Poliomielitis. Dalam: Buku ajar infeksi dan pediatri tropis. Jakarta: Badan Penerbit IDAI; 2008.h.182-94.

3. Miyamura T. Ten years after polio eradication from the WPRO region: Current status and future problems. Vaccine 2012;30:1406-8.

4. Committee on Infectious Diseases. Poliomyelitis prevention: revised recommendations for use of inactivated and live oral poliovirus vaccines. Pediatrics 1999;103:171-2.

5. Committee on Infectious Diseases. Poliomyelitis prevention: Recommendations for use of inactivated poliovirus vaccine and live oral poliovirus vaccine. Pediatrics 1997;99:300-5.

6. Jesus NDH. Epidemics to eradication: the modern history of poliomyelitis. Virol J 2007;4:1-18.

7. Chatterjee A, Vidyant $S$, Dhole TN. Polio eradication in India: Progress, but environmental surveillance and vigilance still needed. Vaccine 2013;31:1268-75.

8. Sandersa BP, Edo-Matasa D, Custersa JHHV, Koldijka $\mathrm{MH}$, Klarena V, Turk M, dkk. PER.C6 ${ }^{\circledR}$ cells as a serum-free suspension cell platform for the production of high titer poliovirus: A potential low cost of goods option for world supply of inactivated poliovirus vaccine. Vaccine 2013;318506.

9. Davis R, Wright PF. Circulating vaccine derived poliovirus and the polio eradication endgame. Pan African Med J 2012;12:109.

10. Committee on Infectious Diseases. Poliovirus. Pediatrics 2011;128:805-8.

11. Modlin JF. The bumpy road to polio eradication. N Engl J Med 362;25:2346-9.

12. Weekly epidemiological record. Inactivated poliovirus vaccine following oral poliovirus vaccine cessation. 2006; 15:137-44. Diakses 10 Juni 2013. Diunduh dari: http://www.who.int/wer.

13. Andrus JK, Thapa AB, Withana N, Fitzsimmons JW, Abeykoon P, Aylward B. A new paradigm for international disease control: lessons learned from polio eradication in southeast asia. Am J Pub Health 2001;91:146-50.

14. WHO. Diakses pada tanggal 12 September 2016. Didapat dari: http://www.polioeradication.org/mediaroom/newsstories/ WHO-Removes-Nigeria-from-Polio-Endemic-List-/tabid/526/ news/1291/Default.aspx

15. WHO. Diakses pada tanggal 12 September 2016. Didapat dari:http://www.polioeradication.org/mediaroom/newsstories/ Global-eradication-of-wild-poliovirus-type-2-declared/tabid/526/ news/1289/Default.aspx 